\title{
IMPROVING THE HIGH-TEMPERATURE PROPERTIES OF A NEW GENERATION OF Fe-Al-O OXIDE-PRECIPITATION-HARDENED STEELS
}

\author{
IZBOLJŠANJE VISOKOTEMPERATURNIH LASTNOSTI NOVE \\ GENERACIJE Fe-Al-O JEKEL ZA OKSIDNO IZLOČEVALNO \\ UTRJEVANJE
}

\author{
Omid Khalaj ${ }^{1}$, Hana Jirková1, Tomáš Janda1 ${ }^{1}$, Ludmila Kučerová1, \\ Tomáš Studecký ${ }^{2}$, Jiř́í Svoboda ${ }^{3}$ \\ ${ }^{1}$ Regional Technological Institute, University of West Bohemia, Univerzitní 22, 306 14, Pilsen, Czech Republic \\ ${ }^{2}$ COMTES FHT a.s., Prümyslová 995, 33441 Dobřany, Czech Republic \\ ${ }^{3}$ Institute of Physics of Materials, Academy of Sciences of the Czech Republic, Zižkova 22, 616 62, Brno, Czech Republic
}

Prejem rokopisa - received: 2018-10-22; sprejem za objavo - accepted for publication: 2019-01-17

doi:10.17222/mit.2018.227

\begin{abstract}
Increasing efficiency in power engineering is conditional on the improvement of the high-temperature properties of structural materials. A new Fe-Al-O Oxide-Precipitation-Hardened (OPH) steel was developed by the authors to dissolve the required amount of $\mathrm{O}$ in the matrix during mechanical alloying and let a fine dispersion of Al oxides precipitate during the hot consolidation. Compared to oxide-dispersion-strengthened (ODS) ferritic steels, excellent oxidation resistance is guaranteed by using $10 \% \mathrm{Al}$ in the matrix. To improve the high-temperature properties of $\mathrm{OPH}$, a series of thermomechanical tests was performed to investigate the recrystallization and grain growth of the microstructures by metallographic analysis. The results show that the heat treatment has a significant influence on the mechanical properties of OPH as well as the microstructure and recrystallization of the grains. It decreased the UTS to almost $25 \%$ of the initial state, while causing plastic deformation. Also, grain growth was observed up to $16 \%$, even with no annealing and applied deformation, which shows a good structure-oriented material.

Keywords: $\mathrm{OPH}$ alloys, grain growth, microstructure, $\mathrm{Fe}-\mathrm{Al}, \mathrm{Al}_{2} \mathrm{O}_{3}$

Izboljšanje visokotemperaturnih lastnosti konstrukcijskih termično stabilnih jekel je pogoj za povečanje učinkovitosti termoenergetskih naprav. Avtorji so razvili novo jeklo na osnovi Fe-Al-O, ki temelji na izločevalnem utrjevanju (OPH; angl.: Oxide Precipitation Hardened) med njegovo ustrezno termično obdelavo. Za to je potrebno raztopiti zahtevano količino kisika v kovinski matrici med mehanskim legiranjem in ustvariti fino disperzijo Al oksidov med njegovo vročo konsolidacijo. V primeru feritnih z oksidno disperzijo utrjenih jekel (ODS; angl.: Oxide Dispersion Strengthened) se doseže odlična odpornost proti oksidaciji, če je v matrici več kot $10 \%$ Al. Avtorji so, da bi izboljšali visokotemperaturne lastnosti izbranega OPH jekla, izvedli vrsto termomehanskih preizkusov in raziskovali pogoje rekristalizacije ter rasti zrn v mikrostrukturi s pomočjo metalografskih analiz. Rezultati analiz so pokazali, da ima toplotna obdelava pomemben vpliv na mehanske lastnosti OPH jekel, kakor tudi na mikrostrukturo in rekristalizacijo kristalnih zrn. Zmanjšanje natezne trdnosti pri prelomu preizkušancev je bilo $25 \%$ glede na začetno stanje po plastični deformaciji. Prav tako so avtorji opazili do $16 \%$ rast zrn, če ni bila uporabljena plastična deformacija, kar kaže na dobro strukturno orientiran material.

Ključne besede: OPH jekla, rast kristalnih zrn, mikrostruktura, $\mathrm{Fe}-\mathrm{Al}, \mathrm{Al}_{2} \mathrm{O}_{3}$
\end{abstract}

\section{INTRODUCTION}

Nowadays, the development of Fe-Al-based steel for high-temperature applications is an important area of research. These material preparation processes have made them significant for their unique properties such as a high ratio of strength to weight and excellent high-temperature oxidation and creep properties. ${ }^{1-6}$ Two classic groups of these metallic materials are nickel-based super alloy single crystals and oxide dispersion strengthened (ODS) ferritic steels. The excellent creep properties of single-crystal super alloys are due to their microstructure, which consists of ordered cube-shaped $\gamma^{\prime}$-precipitates in a volume fraction of about $70 \%$, separated by

*Corresponding author's e-mail:

khalaj@rti.zcu.cz thin channels of disordered $\gamma$ matrix. The instability of the $\gamma^{\prime}$-precipitates due to directional coalescence and/or coarsening above $800{ }^{\circ} \mathrm{C}$ and enormous costs seem to be the biggest disadvantage of single-crystal super alloys. ODS ferritic steels (alloys) consist of a matrix strengthened by a rather fine dispersion of stable oxides (usually $\mathrm{Y}_{2} \mathrm{O}_{3}$ ) with a typical size of 5-30 nm and with a volume fraction below $0.5 \%$. They are usually produced by nanocomposite powder from the matrix and yttrium is produced by mechanical alloying, which is then hot consolidated. ${ }^{7-10}$

Recent research on ODS steels indicates high-temperature strength and excellent creep properties, which are achieved by the dispersion of very fine stoichiometric Y-Ti-O nanoclusters with a size of 3-5 nm. ${ }^{1-14}$ The mechanical properties of ODS steels were improved via 
optimized processing and then a matured level for their applications was achieved. Such processing consists of a controlled thermo-mechanical treatment and lowering the content of the elements $\mathrm{O}, \mathrm{N}, \mathrm{C}$ introduced during mechanical alloying. Both steps lead to a significant increase in fracture toughness at elevated and high temperatures by the improved cohesion of the grain boundaries. Excellent creep properties of the ODS steels are due to the attractive interaction of dislocations with oxides modelled by J. Rösler and E. Arzt ${ }^{15}$, who predicted a significant threshold stress decrease with the coarsening of the oxides. A model for coarsening in multicomponent systems shows that the coarsening kinetics is proportional to the product of the solubility and the diffusion coefficient of oxygen in the matrix. ${ }^{16-18}$ As the solubility of oxygen in the matrix is determined by the chemical stability of the oxide, a significant resistance of chemically reported very stable yttrium particles against coarsening. ${ }^{19-22}$ The high-temperature applications of ODS steels are thus rather limited by the existence of grain boundaries allowing diffusional creep and intergranular damage. That is why the creep properties of fine grained ODS steels are usually much worse than those of coarse-grained ones and the existence of grain boundaries and high processing costs seem to be the biggest disadvantages of ODS steels.

Following the recent findings about the new generations of ODS steels, the authors developed a new, low-cost, Fe-Al- $\mathrm{Al}_{2} \mathrm{O}_{3}$-based ODS steel called Fe-Al-O oxide precipitation-hardened $(\mathrm{OPH})$ steel. The matrix consists of $90 w / \%$ of Fe and $10 w / \%$ of Al. It is solely ferritic, without a phase transformation, up to a temperature of $1500{ }^{\circ} \mathrm{C}$, which is comparable to the mechanical properties of existing $\mathrm{Fe}-\mathrm{Cr}-\mathrm{Y}_{2} \mathrm{O}_{3}$ based ODS steels. This paper concentrates on the mechanical properties of this new OPH steel, microstructure and the phenomenon of recrystallization, which leads to an evaluation of the grain growth.

\section{Powder Mixing}

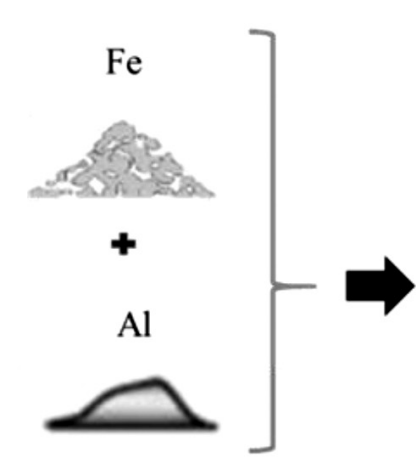

Mechanical Alloying

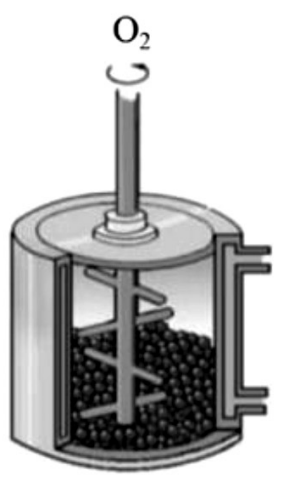

\section{EXPERIMENTAL PART}

\subsection{Material preparation}

$\mathrm{Fe}-\mathrm{Al}$-based $\mathrm{OPH}$ steel is prepared based on a controlled mechanical alloying process, which is highly dependent on the powder metallurgy ${ }^{23}$ (Figure 1). In the first stage, powders consisting of $90 w / \%$ of $\mathrm{Fe}$ and $10 w / \%$ of $\mathrm{Al}$ are mixed with a specific amount of $\mathrm{O}_{2}$ in the form of gas in our own low-energy ball mill capable of evacuation and filling with oxygen. It is equipped with two steel containers (each 24 1), which are filled with 160 (80 in each) steel balls with a diameter of $40 \mathrm{~mm}$. The mill rotation frequency can be adjusted between $20 \mathrm{~min}^{-1}$ and $90 \mathrm{~min}^{-1}$. However, for this study, all the material preparation is done at a constant rate of $75 \mathrm{~min}^{-1}$. During mechanical alloying, the density of defects (dislocations and vacancies) drastically increases in the matrix of the powder and oxygen dissolves in the matrix by being trapped in the defects. The solubility of the interstitial oxygen in the heavily deformed matrix seems to be enormous. In the second stage, the powder changes to a solid solution and is transferred from the milling container into the rolling container (made from a low-alloy steel), without any contact with the air. At the same time, it is evacuated by suction pump (degassed) and sealed by welding. In the next stage, a universal rolling mill is used to process the prepared materials with two steps of hot rolling. First, it is heated to a temperature of $750{ }^{\circ} \mathrm{C}$, rolled to a thickness of $20 \mathrm{~mm}$ and then heated again up to a temperature of $900{ }^{\circ} \mathrm{C}$ and rolled to a thickness of $8 \mathrm{~mm}$ in the final step. All the steps have a rolling speed of $1 \mathrm{~m} / \mathrm{s}$. An approximately 6-mm-thick $\mathrm{OPH}$ sheet, which is covered on both sides by $1-\mathrm{mm}-$ thick scale, from the rolling container, is produced in this way.

Afterwards, the hot-consolidated Fe-Al-O OPH steel is stripped out from the rest of the rolling container and cut into specimens with a water jet. In this study three types of material (Fe-10 w/\% Al ferritic matrix with different particle sizes) differing in $\phi / \%$ of $\mathrm{O}_{2}$ were chosen, as shown in Table $\mathbf{1 .}$

\section{Evacuation and Welding}

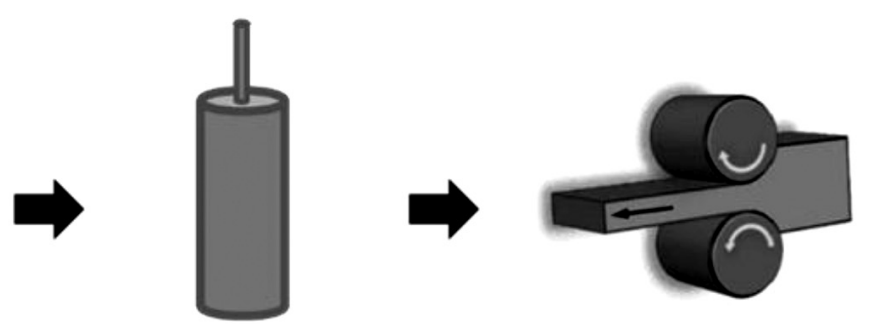

Figure 1: Material preparation process 


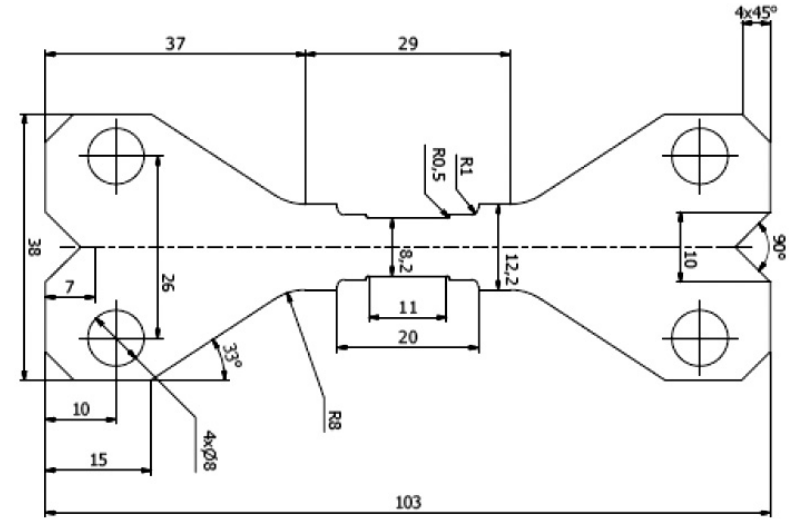

(a)

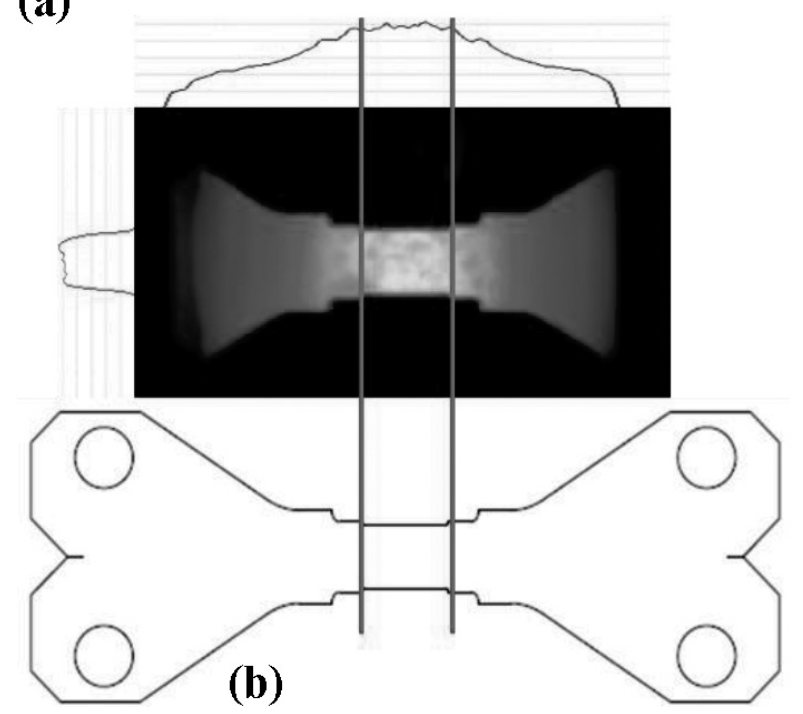

Figure 2: Specimen type 1: a) dimensions in $\mathrm{mm}$, b) temperature field

Table 1: Material Parameters

\begin{tabular}{|c|c|c|c|}
\hline $\begin{array}{c}\text { Material } \\
\text { no. }\end{array}$ & $\begin{array}{c}\text { Material } \\
\text { Type }\end{array}$ & $\begin{array}{c}\text { Milling } \\
\text { time (h) }\end{array}$ & Matrix \\
\hline 1 & OPH Steel & 150 & $\begin{array}{c}\text { austenitic Ni-15Cr-12Fe- } \\
\text { 4Al-4Mo-3Y-2O }\end{array}$ \\
\hline 2 & OPH Steel & 150 & $\begin{array}{c}\text { ferritic Fe-14Cr-8Al- } \\
\text { 4Mo-2Y-1.5O }\end{array}$ \\
\hline 3 & OPH Steel & 150 & $\begin{array}{c}\text { ferritic Fe-14Cr-8Al- } \\
5 \mathrm{Mo}-2 \mathrm{Y}-1.2 \mathrm{O}\end{array}$ \\
\hline
\end{tabular}

\subsection{Specimen preparation}

In order to investigate the mechanical and microstructural properties of $\mathrm{OPH}$ steels, two sample shapes were considered. Specimen type 1 (Figure 2) was considered for tensile tests at higher temperatures. It was selected from other shapes by using a thermal camera to measure the temperature field, as it has the most homogeneous temperature field. The active part width is reduced for the tensile test at room temperature (RT) because of the machine capacity.

Specimen type 2 (Figure 3) is designed to investigate the microstructure and evaluate the grain growth regarding recrystallization during different heat treatments. It was analysed and designed to have four different deformations $(5,8,20$ and 50) \%) by applying the compression force at the same time. The last part of the sample ( $9 \mathrm{~mm}$ height) is designed to demonstrate the section without any deformation on the same heat treatment. To prevent any extra deformation during loading, this type of specimen is held in a hydraulic forging press with two 10-mm-thick side plates.

It should be noted that all the specimens were cut with a water jet in a longitudinal direction (parallel to the rolling direction) and then the still container was removed from the specimens. The thickness of the specimens was approximately $6 \mathrm{~mm}$ after grinding.

\subsection{Testing equipment}

A servo-hydraulic MTS thermomechanical simulator and a hydraulic forging press were used to carry out the experimental tests. A forging machine capable of applying a constant pressure at a constant rate was programmed to apply a force at the same rate to all the samples. The thermomechanical simulator was used to apply various thermomechanical treatments to investigate the flow curves and mechanical properties of the samples. An Olympus GX51 microscope was used for the metallographic analysis of the samples. Cross-sections from the samples were prepared using standard grinding and polishing processes and the microstructure was highlighted with Adler etching.

\subsection{Testing programme}

The test programme was divided into two different groups, as described in Table 2.

The first group of tests was performed to investigate the thermomechanical behaviour of all the materials at different temperatures, looking at single tensile tests with

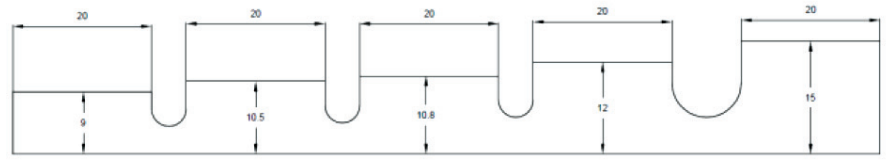

(a)

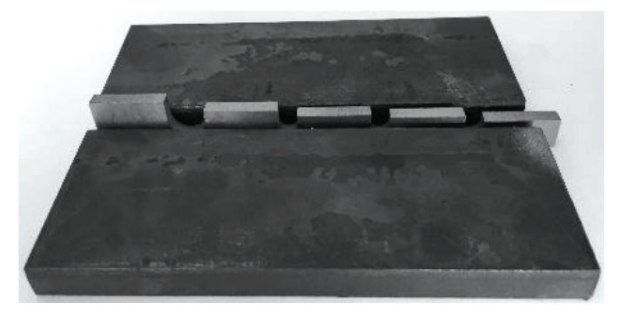

(b)

Figure 3: Specimen type 2: a) dimensions in $\mathrm{mm}$, b) positioning side plates 
O. KHALAJ et al.: IMPROVING THE HIGH-TEMPERATURE PROPERTIES OF A NEW GENERATION ...

Table 2: Parameters of test programme

\begin{tabular}{|c|c|c|c|l|}
\hline Test group & $\begin{array}{c}\text { Holding time } \\
(\mathrm{h})\end{array}$ & $\begin{array}{c}\text { Maximum temperature } \\
\left({ }^{\circ} \mathrm{C}\right)\end{array}$ & $\begin{array}{c}\text { Strain rate } \\
\left(\mathrm{s}^{-1}\right)\end{array}$ & \multicolumn{1}{c|}{ Purpose of tests } \\
\hline $\mathrm{A}$ & - & $800, \mathrm{RT}$ & $\begin{array}{c}1 \cdot 10^{-3} \\
100 \cdot 10^{-3} \\
10000 \cdot 10^{-3}\end{array}$ & $\begin{array}{l}\text { Investigation of } \\
\text { thermomechanical behaviour }\end{array}$ \\
\hline $\mathrm{B}$ & $0,1,20$ & $1150,1200,1250$ & $1 \cdot 10^{-3}$ & $\begin{array}{l}\text { Investigation of microstructure, } \\
\text { hardness, fracture \& grain size }\end{array}$ \\
\hline
\end{tabular}

three different strain rates. The samples were heated by a high-frequency heating system installed on the thermomechanical simulator to the desired temperature in $5 \mathrm{~min}$ and then the tension force was applied with a predefined strain rate up to the failure of the sample and then left to cool to room temperature. The specimen temperature was controlled and maintained in a closed-loop system by thermocouples welded to the middle of the specimen.

The second group of tests were organized to analyse the microstructure, including recrystallization and grain coarsening within different heat treatments. Thanks to the special designation of specimen type 2 (Section 2.2), different deformations $(5,8,20$ and 50) \%) were applied at the same time to investigate how it would affect the recrystallization, which would lead to grain coarsening. It should be noted that all the specimens were also checked with water quenching to simulate immediate cooling (0-hour holding time).

\section{RESULTS AND DISCUSSION}

\subsection{Test group A}

In order to better understand the mechanical properties of all three variants of OPH steel, the tensile tests were performed at RT and $800{ }^{\circ} \mathrm{C}$. Figure 4 shows the tensile stress-strain curves for all materials at different temperatures.

The results showed that, generally, the best mechanical behaviour at RT as well as $800{ }^{\circ} \mathrm{C}$ was found for material 3 (ferritic matrix with less oxygen and a higher amount of Mo). At room temperature materials 1 and 2 exhibit almost the same behaviour and the fracture failure was $971 \mathrm{MPa}$ and $925 \mathrm{MPa}$, respectively. A significantly higher tensile strength of $1561 \mathrm{MPa}$ is measured for material 3 with an elongation of $2.7 \%$. At $800{ }^{\circ} \mathrm{C}$, plastic deformation was observed for materials 2 and 3, and for material 1 a fracture occurred almost immediately after the maximum tensile strength was reached. As is known, necking usually occurs rapidly after the stress reaches the ultimate tensile stress, and the deformation before necking is commonly regarded as uniform elongation. Figure 5 shows the ultimate tensile stress (UTS) of all the materials at RT as well as at $800{ }^{\circ} \mathrm{C}$. It can be seen that there is almost no difference between the UTS of materials 1 and 2 at RT and $800{ }^{\circ} \mathrm{C}$, however there is a significant increase in UTS for material 3 when compared with materials 1 and 2. Usually, at lower temperatures (RT), the material experiences
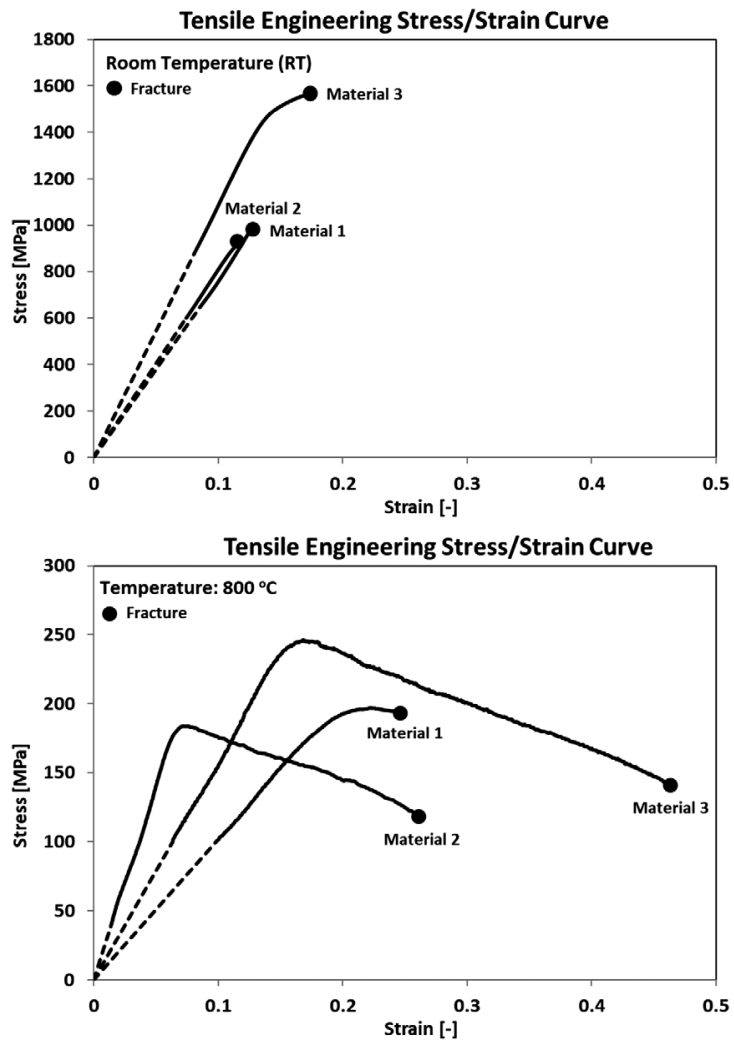

Figure 4: Tensile stress-strain curves at: a) RT, b) $800{ }^{\circ} \mathrm{C}$

(a) RT

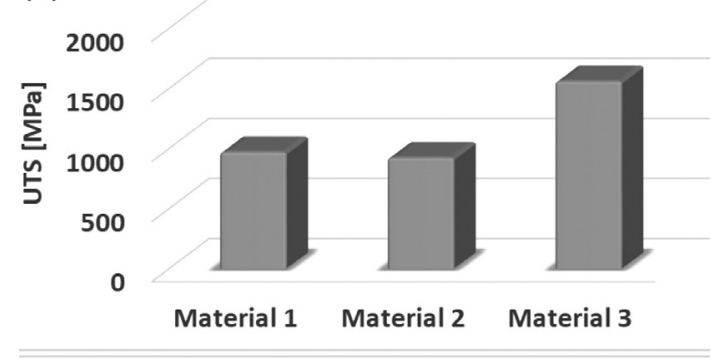

(b) $800^{\circ} \mathrm{C}$

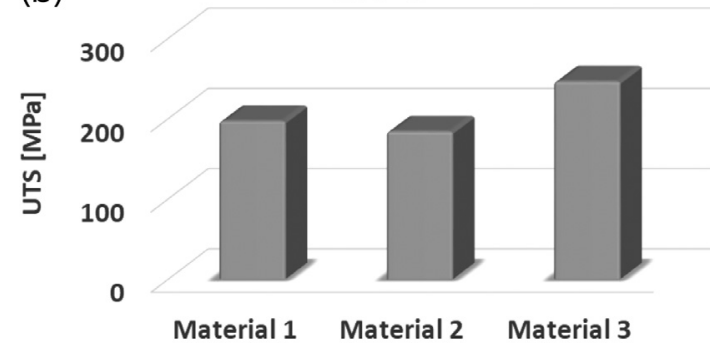

Figure 5: UTS at: a) RT, b) $800{ }^{\circ} \mathrm{C}$ 
work hardening due to the increase of dislocation density, which leads to a rapid increase up to UTS. On the other hand, by increasing the temperature $\left(800{ }^{\circ} \mathrm{C}\right)$, the mobility of dislocations increases as well and causes thermal softening, which could influence the work hardening and lead to a final decrease in UTS. ${ }^{24}$

Figure 6 shows the elastic modulus of all the materials at RT and at $800{ }^{\circ} \mathrm{C}$. The elastic modulus (E) is determined by the tangent modulus of the initial elastic linear phase from the full range of the stress-strain relationship. It is observed that the modulus of elasticity varies slightly at RT and $800{ }^{\circ} \mathrm{C}$; however, all three materials show a similar elastic modulus at each temperature, as their basic components are the same. At RT, it varies in the range from $8 \mathrm{GPa}$ to $11 \mathrm{GPa}$, while it reduces to 1-3 GPa at $800{ }^{\circ} \mathrm{C}$. Material 2 shows a higher E compared to the others at $800{ }^{\circ} \mathrm{C}$, because of a rather different content of fine oxides, which seems to be the reason for its brittleness at $800{ }^{\circ} \mathrm{C}$.

Figure 7 shows the hardness (HV10) test results for all three materials at RT and $800{ }^{\circ} \mathrm{C}$. However, all the tests were carried out at RT. The results at $800^{\circ} \mathrm{C}$ means that the samples after tensile tests at $800{ }^{\circ} \mathrm{C}$ were evaluated by hardness test at RT. The hardness test according to Vickers was performed by using a ZWICK/ ROELL Z2.5 hardness tester with a load of $10 \mathrm{~kg}$ and loading time $11 \mathrm{~s}$ on the surface fracture area of polished samples. The average value was calculated from three measurements. It should be noted that at RT, the hardness was measured on the sample's head as well as the fracture area to see if there would be a major difference between the initial state and the deformed state of the materials.

It can be seen that there is almost no difference between the measured hardness at RT and $800{ }^{\circ} \mathrm{C}$. In addition, the hardness for the initial state of all the
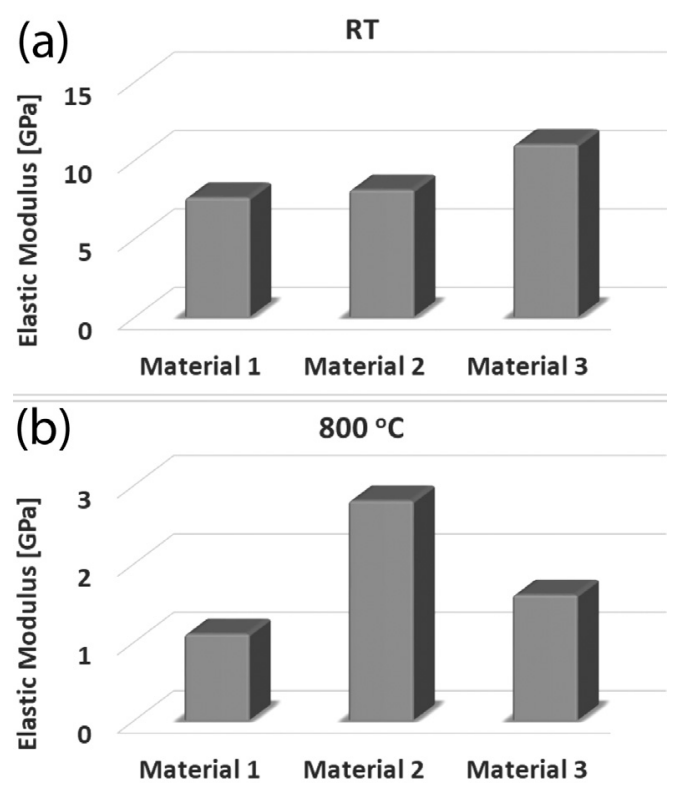

Figure 6: Elastic modulus at: a) RT, b) $800{ }^{\circ} \mathrm{C}$
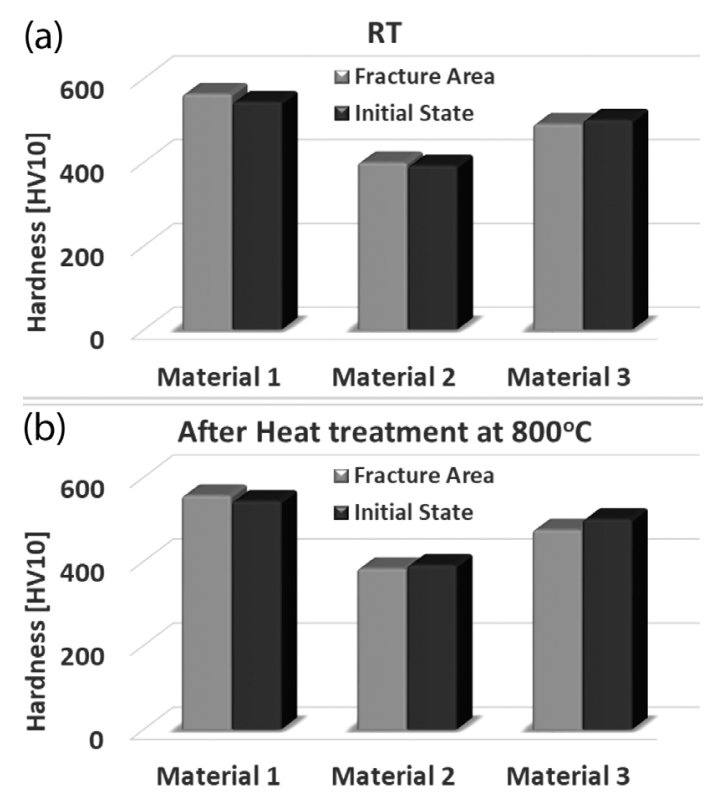

Figure 7: Hardness (HV10) at: a) RT, b) $800{ }^{\circ} \mathrm{C}$

materials has almost no change compared to the fracture area. It confirms that the heat treatment at $800{ }^{\circ} \mathrm{C}$ has almost no influence on the hardness of all three materials. ${ }^{25}$ Besides, Material 2 (ferritic matrix with average oxygen and lower amount of Mo) shows a lower hardness than the others, and this small fluctuation might be attributed to the occurrence of dislocation annihilation

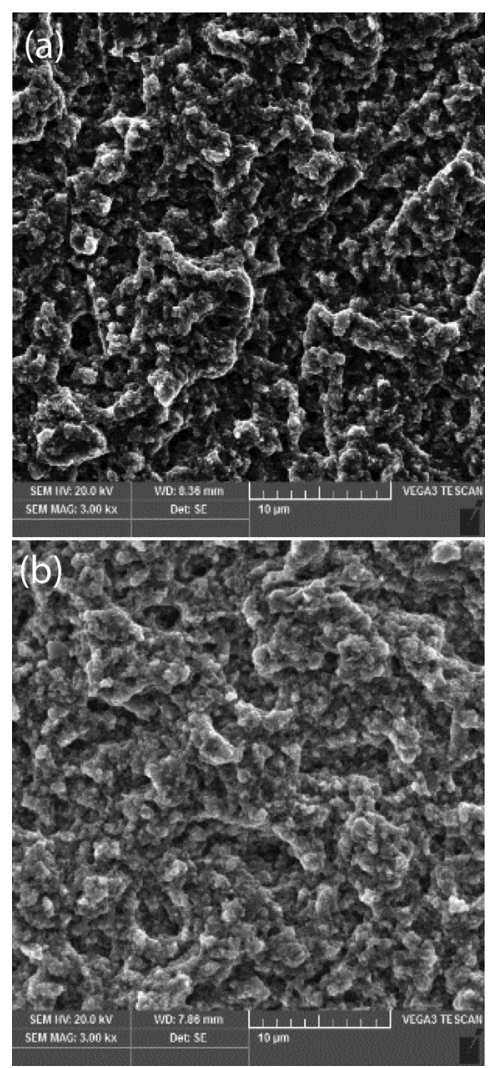

Figure 8: Microstructure of fracture area for Material 1 at: a) RT, b) $800{ }^{\circ} \mathrm{C}$ 

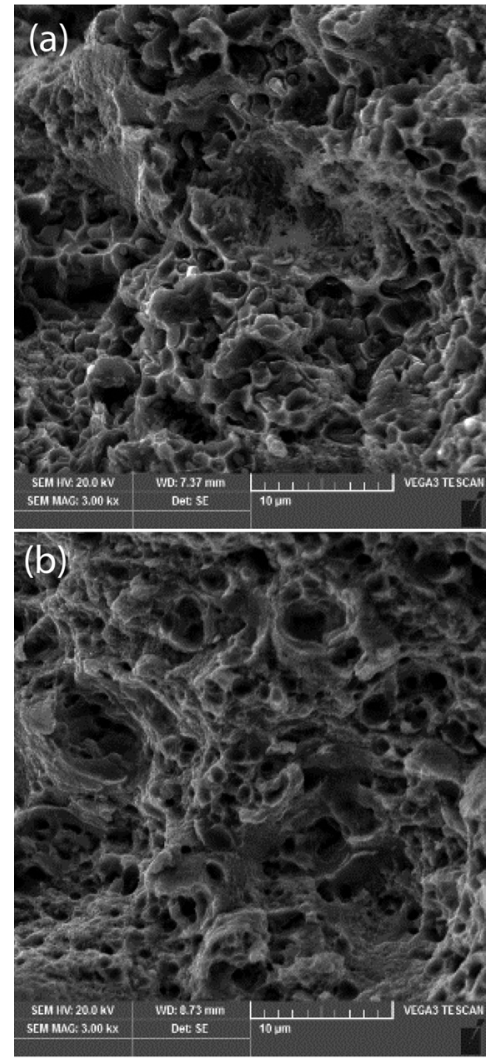

Figure 9: Microstructure of fracture area for Material 2 at: a) RT, b) $800{ }^{\circ} \mathrm{C}$
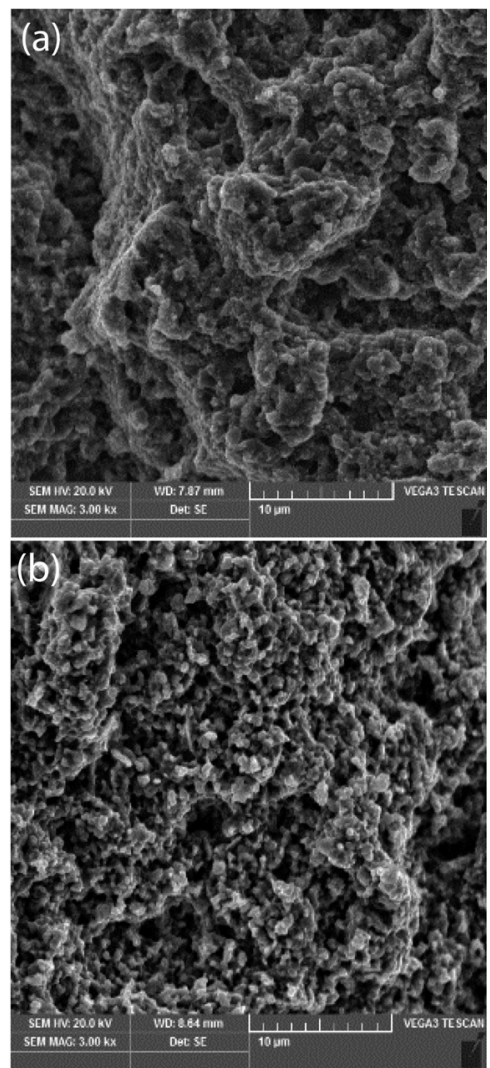

Figure 10: Microstructure of fracture area for Material 3 at: a) RT, b) $800{ }^{\circ} \mathrm{C}$ or rearrangement followed by rapid subgrain growth, or it could be because of the inhomogeneity of the material within the whole container.

Figures 8 to $\mathbf{1 0}$ show the microstructures of fractures under a scanning electron microscope for all three materials at RT and $800{ }^{\circ} \mathrm{C}$. The character of the fractures was very similar for all three materials. Also, the influence of the elevated temperature of $800{ }^{\circ} \mathrm{C}$ was not significant. From the images, it is obvious that the fracture was ductile with a dimpled morphology. In Figure 9a, particles dropping from individual dimples can also be observed.

\subsection{Test group $B$}

As described in Section 2.2, a new specimen shape was designed to investigate the microstructure and evaluate the grain growth with regards to the recrystallization under various deformations during different heat treatments. Before manufacturing the specimens, a numerical analysis was performed to check the possibility of boundaries interference and the location of maximum internal deformation. Analyses were performed using DEFORM $^{\circledR}$, which is an engineering software that enables designers to simulate and analyse metal forming, heat treatment, machining and mechanical joining processes. Several specimen shapes were designed and analysed to minimize the boundary effects and to have a homogenous temperature field as well as the desired deformed area. Figure 11 shows the temperature field of the final specimen shape around the whole surface and inside the middle section of the specimen after applying a vertical load.

The results show that the temperature field remained almost homogenous, especially in the middle of each section, which is so important when materials are recrystallized by applying deformation. Figure $\mathbf{1 2}$ shows the effective total strain of the final specimen in addition to the middle section of the specimen after applying a vertical load.

The results show that the maximum total deformation, which can lead to recrystallization of the grains that would happen in the middle of each section. However, there is some extraordinary deformation on the boundaries because of the lack of boundary restrictions. It can also be seen that, each section has almost no influence on the others in terms of deformation, while they are connected together to have the same temperature and sustain the vertical load at the same time.

Figure 13 shows the hardness (HV10) test results for all three materials without and after (5, 8, 20 and 50)\% of applied deformation with two different annealing times $(0$ and 20$) \mathrm{h}$ at $1200{ }^{\circ} \mathrm{C}$. The Vickers hardness test was performed using a ZWICK/ROELL Z2.5 hardness tester with a load of $10 \mathrm{~kg}$ and loading time $11 \mathrm{~s}$ on the surface of the polished samples. The average value was calculated from three measurements. The results show 
O. KHALAJ et al.: IMPROVING THE HIGH-TEMPERATURE PROPERTIES OF A NEW GENERATION ...

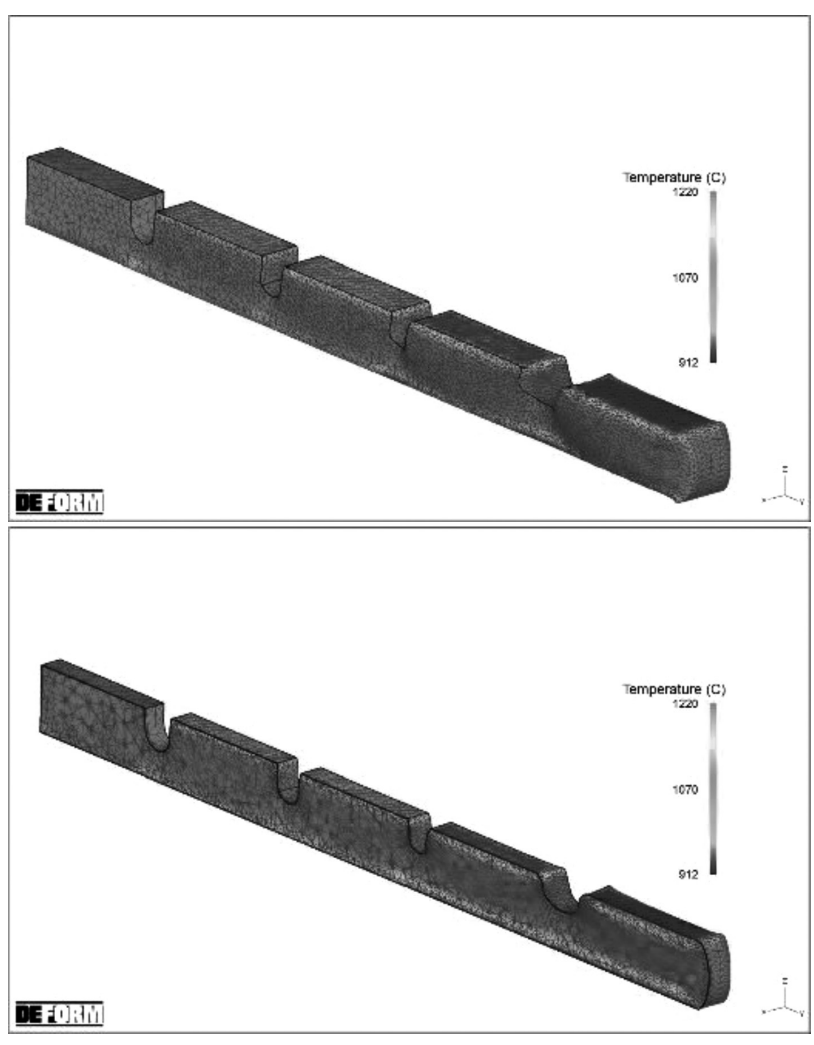

Figure 11: Temperature field at $1200^{\circ} \mathrm{C}$ : a) whole sample, b) middle section

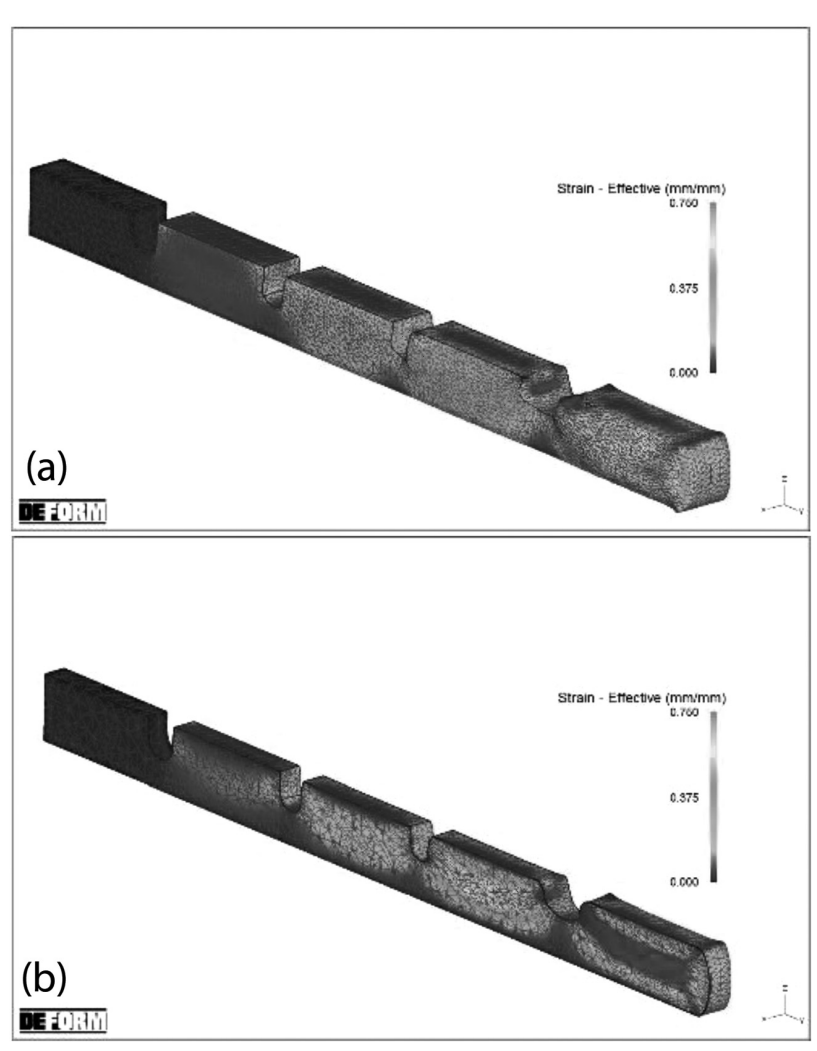

Figure 12: Effective total strain: a) whole sample, b) middle section
Material 1

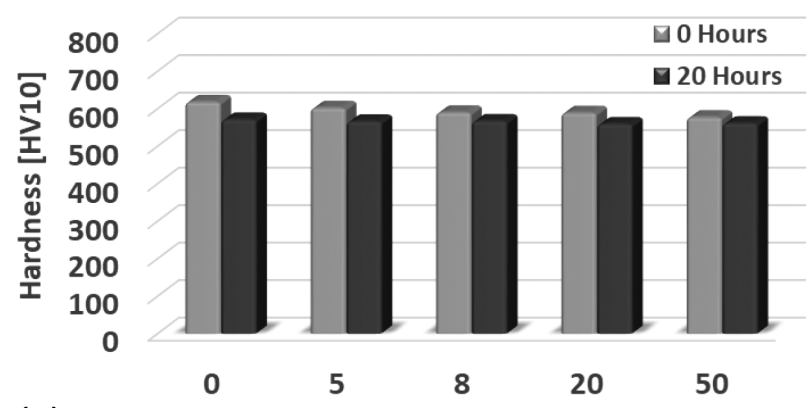

(a) Applied Deformation[\%]

Material 2

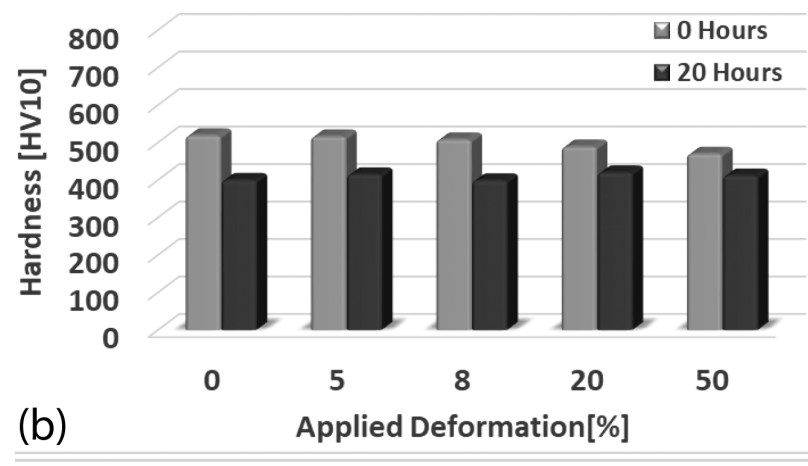

Material 3

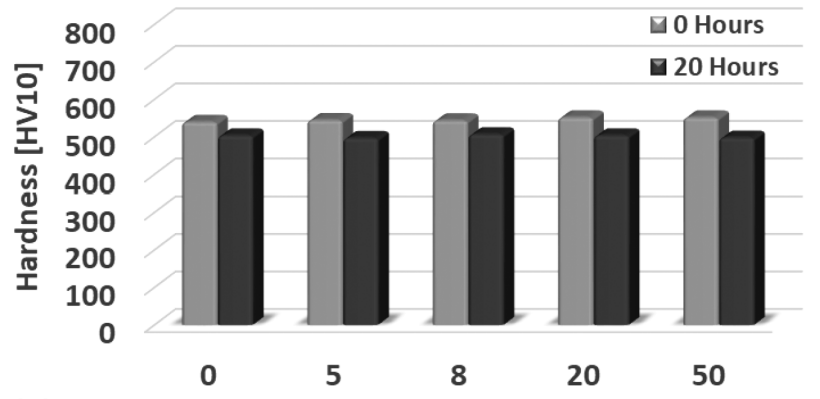

(c)

Applied Deformation[\%]

Figure 13: Hardness (HV10) for a) Material 1, b) Material 2, c) Material 3

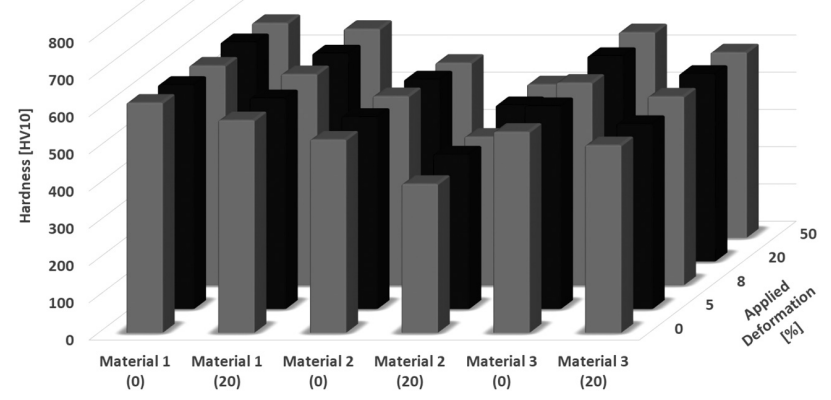

Figure 14: Hardness (HV10) 


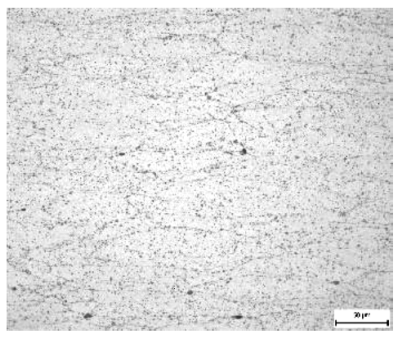

(a)

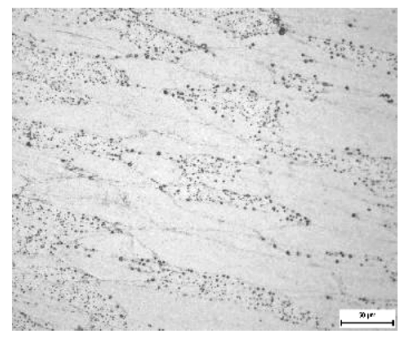

(b)

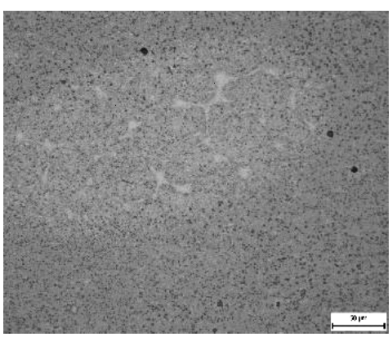

(c)

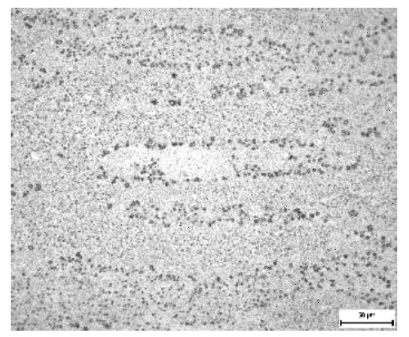

(d)

Figure 15: Microstructure for Material 1: a) without annealing/deformation, b) without annealing/ $50 \%$ deformation, c) $20 \mathrm{~h} 1200{ }^{\circ} \mathrm{C} /$ without deformation, d) $20 \mathrm{~h} 1200{ }^{\circ} \mathrm{C} / 50 \%$ deformation

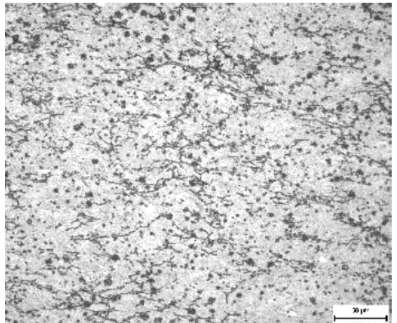

(a)

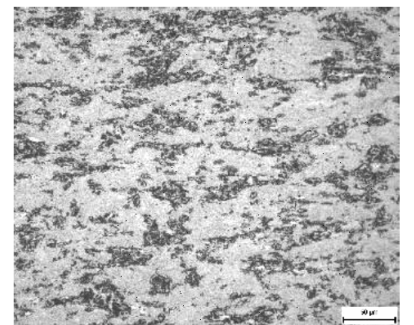

(b)

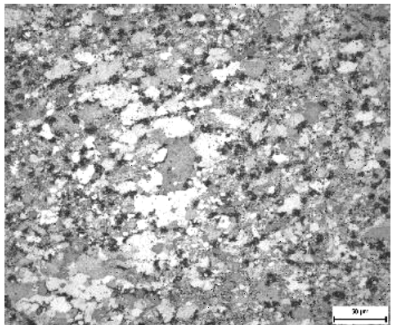

(c)

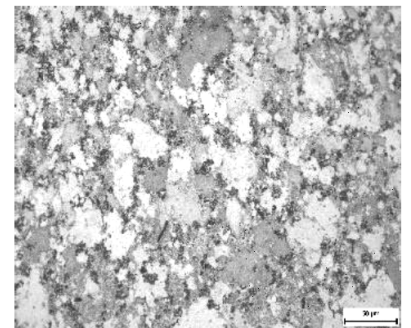

(d)

Figure 16: Microstructure for Material 2: a) without annealing/deformation, b) without annealing/ $50 \%$ deformation, c) $20 \mathrm{~h} 1200{ }^{\circ} \mathrm{C} /$ without deformation, d) $20 \mathrm{~h} 1200{ }^{\circ} \mathrm{C} / 50 \%$ deformation

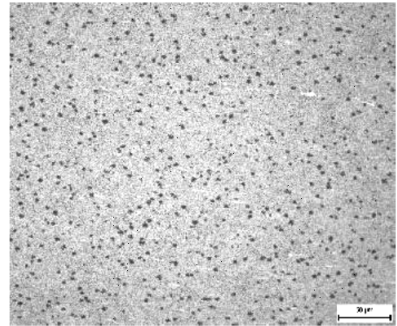

(a)

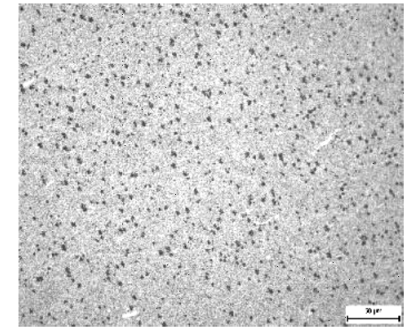

(b)

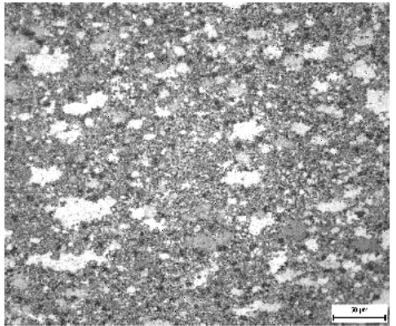

(c)

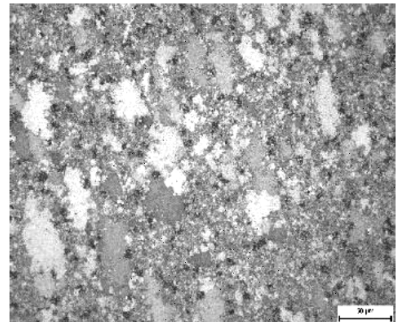

(d)

Figure 17: Microstructure for Material 3: a) without annealing/deformation, b) without annealing/ $50 \%$ deformation, c) $20 \mathrm{~h} 1200{ }^{\circ} \mathrm{C} /$ without deformation, d) $20 \mathrm{~h} 1200{ }^{\circ} \mathrm{C} / 50 \%$ deformation

that the diversity of the chemistries involved in the material components as well as the heat treatment and mechanical history of all materials have an important role in the hardness value.

It can be see that the hardness fluctuated in a range of $500 \mathrm{HV} 10$ to $600 \mathrm{HV} 10$ for all three materials without annealing. It also shows that annealing at $1200{ }^{\circ} \mathrm{C}$ for $20 \mathrm{~h}$ decreased the hardness in a range from $10 \%$ to 20 $\%$ for all the materials. For a better comparison, Figure 14 shows the hardness (HV10) for all materials without and after $(5,8,20$ and 50) \% of applied deformation with two different annealing times ( 0 and 20$) \mathrm{h}$ at $1200{ }^{\circ} \mathrm{C}$. It can be seen that Material 2 with 20-hour annealing at $1200{ }^{\circ} \mathrm{C}$ has the minimum hardness, near to $400 \mathrm{HV} 10$, while Material 1 with no annealing has the maximum hardness of around 620 HV10.

It is clear that by increasing the applied deformation, there is almost no change in the hardness of the materials for any of the holding times, while annealing has a significant influence on all three materials. On the other hand, annealing has less influence on the specimens with higher deformation. For Material 2, a 20-hour annealing at $1200{ }^{\circ} \mathrm{C}$ reduced the hardness from $519 \mathrm{HV} 10$ to 400 HV10 for the sample with no deformation, while it reduced the hardness from $470 \mathrm{HV} 10$ to $412 \mathrm{HV} 10$ for the sample with $50 \%$ deformation, which could be attributed to the occurrence of dislocation annihilation or rearrangement followed by rapid subgrain growth.

Figures 15 to 17 show the microstructures of all three materials without and after $50 \%$ deformation, without and with 20 -hour annealing time at $1200{ }^{\circ} \mathrm{C}$. An optical microscope was used to image the microstructure at the grain and subgrain scale for all deformations $(0,5$, 8,20 and 50) \%; however, due to the large number of images, only those from minimum deformation (0\%) and maximum deformation $(50 \%)$ are presented.

The structure consisted of a solid solution with spherical particles of yttrium and aluminium oxide. It can be seen that almost all three materials recrystallized 
(a)

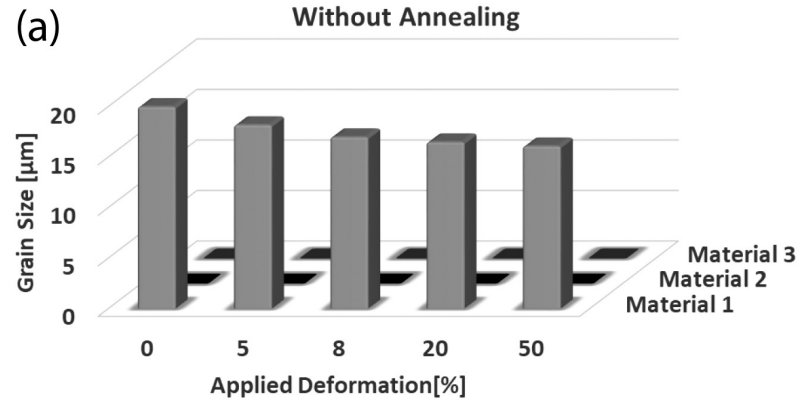

(b)

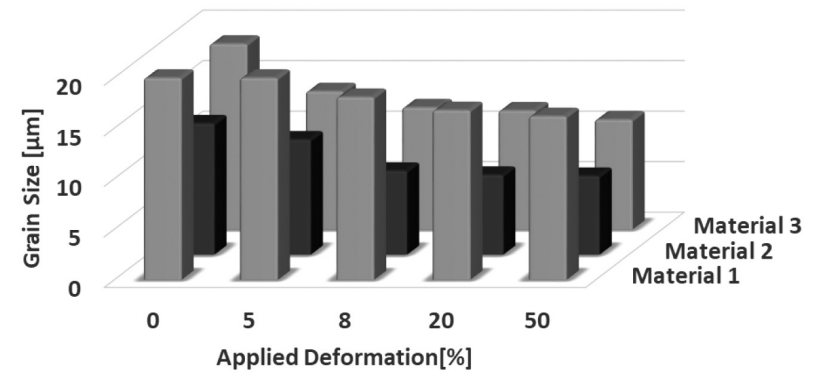

Figure 18: Average grain size: a) without annealing, b) anneal 20 $\mathrm{h} / 1200{ }^{\circ} \mathrm{C}$

over $70 \%$ after annealing; however, only material 1 recrystallized without annealing (Figures 15a and 15b).

Differences in recrystallization between Material 1 and Materials 2 and 3 are due to different alloying. Material 1 contains a high nickel content compared to Materials 2 and 3. For Material 1, grain boundaries of the solid solution are clearly visible even in a state without deformation and annealing (Figure 15a). The $50 \%$ deformation led to austenitic grain elongation (Figure 15b). The annealing at $20 \mathrm{~h}$ caused the partial coarsening of the particles (Figures 15 c and 15d). For Materials 2 and 3 with a ferrite matrix, the recrystallization started after $20 \mathrm{~h}$ of annealing time (Figures 16 and 17).

Figure 18 shows an overview of the grain sizes of all three materials before and after annealing for different applied deformations $(0,5,8,20$ and 50) \%. The grain sizes were measured according to ASTM E112 using in-house software developed by the authors. It measures

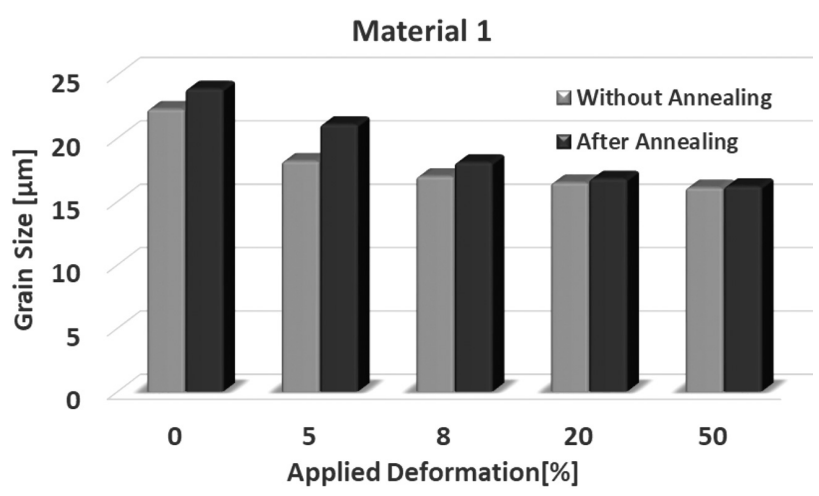

Figure 19: Average grain size for Material 1 before/after annealing

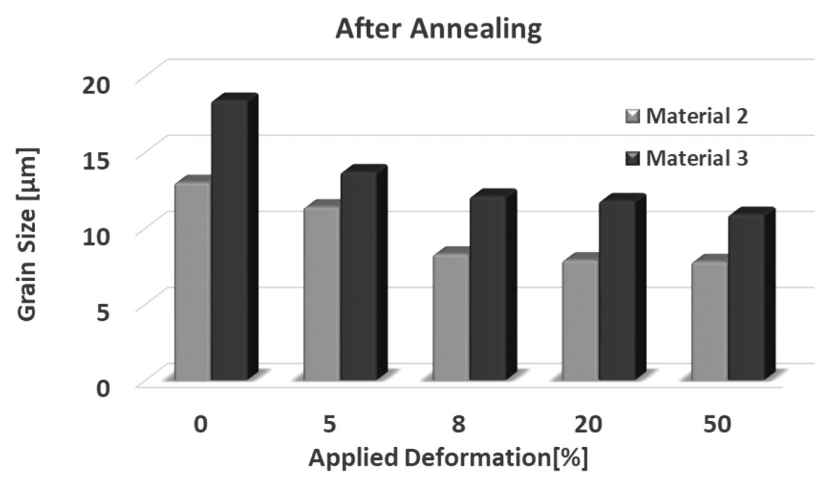

Figure 20: Average grain size for Materials 2 and 3 after annealing

using the intersection method for longitudinal and transverse directions, and both values were then averaged and reported as the average grain size. As Materials 2 and 3 had a very fine structure, it was not possible to measure the grain sizes, however it is expected that small subgrains up to $0.5 \mu \mathrm{m}$ may form within the microstructure. So in Figure 18a, only the measurements for Material 1 are presented. The applied deformation did not cause any significant refinement of the grains. Based on the grain size measurements for all three materials after $20 \mathrm{~h}$ of annealing at $1200{ }^{\circ} \mathrm{C}$, Figure $\mathbf{1 8 b}$ shows that Material 2 has the lowest average grain size after annealing. The grain size was between $7.8 \mu \mathrm{m}$ to $13 \mu \mathrm{m}$. The structure after annealing is, when compare to its initial state, almost completely recrystallized.

In order for a better comparison, Figure 19 shows the average grain size for Material 1 before and after annealing. It can be seen that the difference between the grain sizes of the samples with and without annealing decreased as the applied deformation increased. The maximum recrystallization is found at $5 \%$ deformation, which increased the grain size from $18.2 \mu \mathrm{m}$ to $21.1 \mu \mathrm{m}$, equal to almost $16 \%$. At higher deformation, annealing has almost no effect on the grain coarsening, which confirmed the previous findings of the authors. ${ }^{25}$

Figure 20 shows a comparison of the average grain sizes of Materials 2 and 3 after annealing for $20 \mathrm{~h}$ at $1200{ }^{\circ} \mathrm{C}$. It is clear that Material 3, with a higher amount of Mo and a lower amount of $\mathrm{O}$, has a larger grain size than Material 2. Within all the applied deformations, the grain sizes in Material 3 are almost $40 \%$ larger than in Material 2, which explains the better mechanical properties described in the previous sections.

\section{CONCLUSIONS}

Improving the high-temperature thermomechanical properties of a new OPH steel was investigated using a number of different tests. The results outline the influence of thermomechanical treatments on the microstructure and grain growth as well as mechanical properties such as UTS and hardness. Three materials, differing in their chemical components and matrix, were 


\section{O. KHALAJ et al.: IMPROVING THE HIGH-TEMPERATURE PROPERTIES OF A NEW GENERATION ...}

tested under different conditions. All the materials were simple to prepare, with a low cost of the basic materials. The results show that there is a significant reduction in UTS by increasing the temperature from RT to $800{ }^{\circ} \mathrm{C}$, while softening happened after hardening at higher temperatures. Annealing with different holding times and applied deformations caused an almost 10-20\% reduction in the hardness of the materials, especially Material 2 (ferritic Fe-14Cr-8Al-4Mo-2Y-1.5O). However, it significantly affected the average grain size of all three materials. A higher applied deformation led to smaller grain size, while annealing improved the grain coarsening. However, at higher deformation (more than $8 \%$ ), annealing had no effect on increasing the average grain size of the OPH material.

\section{Acknowledgements}

This paper includes results created within the project 17-01641S Improvement of Properties and Complex Characterization of New Generation Fe-Al-O Based Oxide Precipitation Hardened Steels subsidised by the Czech Science Foundation from specific resources of the state budget of the Czech Republic for research and development.

\section{REFERENCES}

${ }^{1}$ V. Shankar Raoa, R. G. Baligidadb, V. S. Rajaa, Effect of Al content on oxidation behaviour of ternary Fe-Al-C alloys, Intermetallics, 10 (2002), 73-84, doi:10.1016/S0966-9795(01)00106-6

${ }^{2}$ C. T. Liu, J. O. Stiegler, F. H. Fores, Ordered intermetallics, Metals handbook, Vol. 2, Metals Park (OH), ASM Int., 1990, 920

${ }^{3}$ J. H. De Van, P. F. Tortorelli, Behavior of iron aluminides in oxidizing and oxidizing/sulfidizing environments, Materials Science and Engineering A, 153 (1992) 2, 573-577, doi:10.1016/0921-5093 (92)90253-W

${ }^{4}$ P. F. Tortorelli, K. Natesan, Critical factors affecting the high-temperature corrosion performance of iron aluminides, Materials Science and Engineering A, 258 (1998) 2, 115-125, doi:10.1016/ S0921-5093(98)00924-1

${ }^{5}$ U. Prakash, R. A. Buckley, H. Jones, C. M. Sellars, Structure and properties of ordered intermetallics on the Fe-Al system, ISIJ Int. 31 (1991) 10, 1113-1126, doi:10.1016/0142-1123(92)90522-E

${ }^{6}$ O. Khalaj, B. Mašek, H. Jirkova, A. Ronesova, J. Svoboda, Investigation on new creep and oxidation resistant materials, Mater. and Technol., 49 (2015) 4, 173-179, doi:10.17222/mit.2014.210

${ }^{7}$ T. M. Pollock, A. S. Argon, Directional coarsening in nickel-base single crystals with high volume fractions of coherent precipitates, Acta Metallurgica et Materialia, 42 (1994) 1859, doi:10.1016/ 0956-7151(94)90011-6

${ }^{8}$ J. Svoboda, P. Lukáš, Model of creep in -oriented superalloy single crystals, Acta Mater., 46 (1998) 3421, doi:10.1016/S1359-6454 (98)00043-3
${ }^{9}$ J. Svoboda, P. Lukáš, Creep deformation modelling of superalloy single crystals, Acta Mater., 48 (2000) 10, 2519-2528, doi:10.1016/ S1359-6454(00)00078-1

${ }^{10}$ B. Mašek, O. Khalaj, Z. Nový, T. Kubina, H. Jirkova, J. Svoboda, C. Štádler, Behaviour of new ODS alloys under single and multiple deformation, Mater. Tehnol., 50 (2016) 6, 891-898, doi:10.17222/ mit.2015.156

${ }^{11}$ O. Khalaj, B. Mašek, H. Jirková, J. Svobodá, D. Bublíková, Influence of thermomechanical treatment on grain growth behaviour of new $\mathrm{Fe}-\mathrm{Al}$ based alloys with fine $\mathrm{Al}_{2} \mathrm{O}_{3}$ precipitates, Mater. Tehnol., 51 (2017) 5, 759-768, doi:10.17222/mit.2016.232

${ }^{12}$ M. A. Auger, V. de Castro, T. Leguey, A. Muñoz, R. Pareja, Microstructure and mechanical behavior of ODS and non-ODS Fe-14Cr model alloys produced by spark plasma sintering, Journal of Nuclear Materials, 436 (2013) 5, 68-75, doi:10.1016/j.jnucmat. 2013.01.331

${ }^{13}$ M. Kos, J. Ferces, M. Brnucko, R. Rudolf, I. Anzel, Pressing of partially oxide-dispersion-strenghtened copper using the ECAP process, Mater. and Technol., 48 (2014) 3, 379-384

${ }^{14}$ M. Misovic, N. Tadic, M. Jacimovic, M. Janjic, Deformations and velocities during the cold rolling of aluminium alloys, Mater. and Technol., 50 (2016) 1, 59-67, doi:10.17222/mit.2014.250

${ }^{15}$ J. Rösler, E. Arzt, A new model based creep equation for dispersion strengthened materials, Acta Metall., 38 (1990) 67, doi:10.1016/ 0956-7151(90)90223-4

${ }^{16}$ F. D. Fischer, J. Svoboda, P. Fratzl, A thermodynamical approach to grain growth and coarsening, Phil. Mag., 83 (2003) 1075, doi:10.1080/0141861031000068966

${ }^{17}$ A. Grajcar, Microstructure evolution of advanced high-strength trip-aided bainitic steel, Mater. Tehnol., 49 (2015) 5, 715-720, doi:10.17222/mit.2014.154

${ }^{18}$ B. Sustarsic, I. Paulin, M. Godec, S. Glodez, M. Sori, J. Flasker, A. Korosec, S. Kores, G. Abramovic, DSC/TG of Al-based alloyed powders for P/M applications, Mater. Tehnol., 48 (2014) 4, 439-450

${ }^{19}$ P. Krautwasser, A. Czyrska-Filemonowitz, M. Widera, F. Carsughi, Thermal stability of dispersoids in ferritic oxide strengthened alloys, Mater. Sci. Eng. A, 177 (1994) 199, doi:10.1016/0921-5093 (94)90491-X

${ }^{20}$ F. Tehovnik, J. Burja, B. Podgornik, M. Godec, F. Vode, Microstructural evolution of Inconel 625 during hot rolling, Mater. Tehnol., 49 (2015) 5, 899-904, doi:10.17222/mit.2015.274

${ }^{21}$ A. Kocijan, I. Paulin, C. Donik, M. Hocevar, K. Zelic, M. Godec, Influence of different production progresses on the biodegradability of AN FeMn17 alloy, Mater. Tehnol., 50 (2016) 5, 805-811, doi:10.17222/mit.2016.055

${ }^{22}$ H. Dong, L. Yu, Y. Liu, C. Liu, H. Li, J. Wu, Enhancement of tensile properties due to microstructure optimization in ODS steels by zirconium addition, Fusion Engineering and Design, 125 (2017), 402-406, doi:10.1016/j.fusengdes.2017.03.170

${ }^{23}$ D. Kumar, U. Prakash, V. V. Dabhade, K. Laha, T. Sakthivel, High yttria ferritic ODS steels through powder forging, Journal of Nuclear Materials, 488 (2017), 75-82, doi:10.1016/j.jnucmat.2016.12.043

${ }^{24}$ S. Upadhayaya, H. Lib, P. Bowenb, A. Rabieia, A study on tensile properties of alloy 709 at various temperatures, Materials Science and Engineering A, 733 (2018) 22, 338-349, doi:10.1016/ j.msea.2018.06.089

${ }^{25}$ O. Khalaj, H. Jirková, B. Mašek, P. Hassasroudsari, T. Studecky, J. Svobodá, Using thermomechanical treatments to improve grain growth of new-generation ODS alloys, Mater. Tehnol., 52 (2018) 4, 475-482, doi:10.17222/mit.2017.148 